DOI: $10.52950 /$ SS.2021.10.2.002

\title{
IS THERE A TRADE-OFF BETWEEN FINANCIAL REWARDS AND OTHER JOB BENEFITS? DIFFERENT CAREER PATHWAYS FOR TWO GROUPS OF MANAGEMENT STUDENTS.
}

\section{LEIV OPSTAD}

\begin{abstract}
:
The unemployment rate in Norway is low. More than 30 per cent work in the public sector and there is a shortage of labour, especially in the health and education sectors. This article seeks to find out more about why some choose to study within health and education and pursue a career there while others put finances or business education as their priority. Which factors influence this choice? Students' responses to questionnaires reveal that there are some significant differences. The results indicate a trade-off between high salaries and other job benefits. Compared to business and economics students, financial rewards count for less for those selecting public sector work. They accept lower wages in compensation for job security and personal contentment. Other factors that have implications for educational choices are personal characteristics (Big Five) and interests. Furthermore, there is a substantial gap between females selecting business and financial education and females who prefer a personal-oriented job in the public sector. The methods used in this paper are comparison of means (t-test) and standard linear regression.
\end{abstract}

\section{Keywords:}

Public and private sectors, job benefits, financial rewards, management, career, Big Five personality traits

JEL Classification: J28, J30, J45

\section{Authors:}

LEIV OPSTAD, Norwegian University of Science and Technology, Norway, Email: leiv.opstad@ntnu.no

\section{Citation:}

LEIV OPSTAD (2021). Is there a Trade-Off between Financial Rewards and Other Job Benefits? Different Career Pathways for two Groups of Management Students.. International Journal of Social Sciences, Vol. X(2), pp. 15-30., 10.52950/SS.2021.10.2.002 


\section{Introduction}

Today, students can choose between many majors. Admission requirements can set limits, but for skilled students this is no obstacle. There is a lot of literature analysing what determines students' choice of study direction (Soutar \& Turner, 2002). Career patterns depend on the selected working sector (Tshirhartet al., 2008). There is a psychological contract that varies among the sectors (Houston, 2000). In this analysis, we will investigate this in more detail with two completely different student groups. The first consists of undergraduates within economics and business majors aged between 20 and 30 and with limited professional experience. The second group consists of persons with education or health and welfare majors. These are persons with several years' professional experience in the public sector, and they are mainly between 30 and 45 years old. About 40 per cent of this group are in a leadership position, such as principal of an elementary school. Several universities offer further education within management and administration, such as a Master's in public administration (MPA). The participants are teachers and nurses who want more administrative knowledge and therefore probably have career ambitions. The purpose of this article is to compare the two groups. What are the common features and what distinguishes these two groups in relation to work, career, ambitions, abilities, preferences and personal characteristics (Big Five personality traits)? This is useful knowledge when designing and adapting the study programmes to different target groups.

\section{Big Five Personality traits}

The Big Five personality taxonomy (Costa \& McCrae, 1995) has been a very popular instrument in research worldwide. It is the most used approach for measuring personal characteristics (Roccas et al., 2002). In a recently published article, Hager (2021) applied this theory within management. The personality traits have five dimensions: extraversion, agreeableness, conscientiousness, emotional stability, and openness to experience. Those who score high on extraversion are outgoing, like to socialise, are talkative and active. High scores on agreeableness mean being concern about other people, having sympathy towards others, being cooperative and helpful. Individuals with high values in conscientiousness are well organised, hardworking, goal-focused and punctual. Emotional stability is the opposite of neuroticism. High scores on this trait are connected with being calm, secure and emotionally stable. Individuals with a high score on the dimension openness to experience tend to be culturally interested, open minded and have intellectual curiosity.

\section{Literature Review}

\section{Career and Job Attitude}

Students' career attitudes matter (Jackson \& Wilton, 2016). According to Baker et al. (2018), expected labour market outcomes are a key factor in explaining students' selection of study field. These include factors like the possibility of finding a relevant job, job security, wellbeing at work, wages, etc. Wiswall and Zafar (2015) reported a significant correlation between expecting higher earnings and choice of major. The authors found expected enjoyment to be a more important factor when students select a major. However, the students have limited and sometimes incorrect knowledge of future career opportunities. In the analysis by Baker et al. (2018), only 40 per cent of students managed to rank wages across categories of major. Some 
underestimated salaries while others overestimated. A similar tendency was seen in the likelihood of getting a good and relevant job. This implies that many students make their choice of study field based on incorrect or incomplete information.

\section{Private versus Public Sector}

Prior literature has suggested there are differences between private and public employees (Houston, 2000; Levitats \& Vigoda-Gadot, 2020; Prysmakova, 2020). People working in the public sector are less motivated by financial rewards: increased wages are a more important incentive in the private sector. Many individuals might prefer to work in the public sector due to the job security. Furthermore, public employees seem to be less attracted to prestige and status than those in the private sector. There is a tendency for public employees to be more concerned with helping others and performing work that is meaningful to society. Hence, they have more focus on accomplishments that give benefit to others than those working in the non-public sector. A sense of meaningful work is important for public employees, while private employees are more concerned with career and promotion.

Prior work experience, reputation and information via one's network have implications for the choice of sector to work in (Tshirhart et al., 2008). According to this author essential factors for choosing the public sector are the option to have work that allows one to help others and the possibility of long-term employment. People who consider high income as crucial tend to choose the private sector. Even though there are different incentive systems in the private and public sectors, Quinn et al. (2019) reported many similarities in terms of career opportunities between public and private sector employees.

Hübler and Hübler (2006) discussed if there was a trade-off between wages and job security. Must workers accept lower wages in order to get safer jobs? According to the authors, empirical research showed mixed results. Nor did Yu and Kuo (2017) manage to demonstrate any substitution effect between wage levels and job security. This is a surprising result since economic theory and conventional wisdom dictate that one is rewarded for taking greater risks. However, Redmond and McGuinness (2019) reported a trade-off between high wages and other job characteristics. Job security, being close to home and personal preferences are significantly related to wage levels. Since women tend to emphasise these factors more than men, more women than men prefer to work in the public sector with lower wages than men get in the private sector. The authors claim this might explain some of the current salary gap between women and men. Lechner et al. (2018) also pointed out the gender gap in work values. Women valued social relationships and job security higher than men, and were less concerned with wage levels and financial rewards.

\section{Gender and Career Preferences}

The conclusion of the meta-analysis by Su et al. (2009) is that males prefer to work with objects to a higher degree than females, while females prioritise working with people. They are socially oriented and prefer personal-oriented occupations. Many women are motivated by altruism to help others and do something that benefits the society. This effect is not so strong among men.

\section{Labour Market and Personality Traits}

Lakhal et al. (2012) investigated the relationship between choice of major and personality traits, finding that students in quantitative-oriented majors like finance and economics scored lower on emotional stability, extraversion and agreeableness, and higher on conscientiousness. The 
results are much in line with the findings of Lievens et al. (2002). Clariana (2013) compared business students with education students and reported significantly higher emotional stability values for business students. Furthermore, the business students achieved higher values for openness, and lower scores on agreeableness and conscientiousness, but none of these values were significant. For extraversion, there was no difference. Personal characteristics have implications for the choice of study field, but the research showed slightly varying results (Vedel, 2016).

Job security is linked to the Big Five traits (Wu et al., 2020). The authors found a positive link between job security and conscientiousness and agreeableness, and a negative link with emotional stability. Job insecurity can have negative effect on mood and effort.

Success in the labour market is positively related to emotional stability (Judge et al., 1999; Sui et al., 2021) and to conscientiousness (Howard \& Bray, 1990; Sui et al., 2021). Individuals who can handle stress, work hard and operate purposefully achieve career advancement. Extraversion is also linked to career success (Seibert \& Kraimer, 2001). For some jobs, and perhaps especially in the public sector, it may be advantageous to show a willingness to cooperate and to compromise. There is a positive correlation between social engagement and the dimensions of conscientiousness and agreeableness (Cox et al., 2010). Agreeableness seemed to be a predictor of the social aspect of leadership, while conscientiousness is more related to task-oriented leadership (Cogliser et al., 2012). Prior research has suggested a positive link between social engagement and the two traits of agreeableness and conscientiousness (Celik \& Oral, 2016).

Personality is related to the educated person's choice of professional life (Gokoglan \& Ozen Bekar, 2021). Being a leader in nursing and healthcare can require different characteristics from being a leader in other sectors. Nurse managers must show care, pay attention to others, avoid conflicts by using a compromising strategy, and document useful results. This mean that those persons should have high scores in agreeableness and emotional stability, but they also need to be conscientiousness and extravert. Therefore, it is not surprising that nurse managers achieve high values in these personality traits, and especially in agreeableness. There seemed to be a positive relationship between organisational commitment and the two personality traits agreeableness and conscientiousness (Asif et al., 2015; Celik \& Oral, 2016).

Principals and teachers may need some of the same qualities. Zaidi et al. (2013) found the personality traits extraversion, agreeableness, openness and conscientiousness all to be positively related to work engagement among teachers.

It is not obvious how the personality trait of openness differs between public and private employees, but Leóna (2017) reported higher values among those working in the public sector. It is challenging to be a school headmaster and there are many different considerations (Lisnerova \& Urbanová, 2021).

\section{Hypotheses}

Based on the theory, the available literature and the purpose of this article, the following hypotheses are postulated: 
Hypothesis $1(\mathrm{H} 1)$ : There is a trade-off between high wages and other job qualities for Group 1 and Group 2.

Hypothesis $2(\mathrm{H} 2)$ : There is a link between personality traits and work preferences.

The model is graphically illustrated in Figure 1. In this approach, two relatively open hypotheses are selected. This is done to capture different dimensions. Based on theory and the literature review, it is reasonable to assume, for example, that business and economics students achieve higher financial rewards, while greater job security and other benefits matter more for those belonging to the education and health sectors. These factors will be followed up in this paper. Hypothesis 1 will be analysed by comparing average values and use of t-test, while hypothesis 2 will be assessed applying standard linear regression.

\begin{tabular}{|l|l|}
\hline $\begin{array}{l}\text { Chosen } \\
\text { educational } \\
\text { course }\end{array}$ & $\begin{array}{l}\text { Financial rewards } \\
\text { Other job benefits } \\
\text { Career } \\
\text { Development skills } \\
\text { Personality } \\
\text { traits }\end{array}$ \\
\hline
\end{tabular}

Figure 1. The model

\section{Data and Methodology}

\section{The Sample}

The data are from autumn 2019 and were collected from students from three different universities. Business and economics students (Group 1) are all from the Norwegian University of Science and Technology (NTNU). The other students are from three schools (Group 2): six from NTNU, 14 from VID University and 29 from the Western University of Applied Sciences. The reason for so few students from NTNU is that the MPA programme is for students from different backgrounds and this survey includes only those linked to education and healthcare (see Table 1).

Table 1. The sample

\begin{tabular}{lccc}
\hline Students & Males & Females & Total in the survey \\
\hline Business and economics (Group 1) & 38 & 48 & 86 \\
Education and healthcare (Group 2) & 5 & 44 & 49 \\
\hline All & 43 & 92 & 135 \\
\hline
\end{tabular}

The students responded to the questions during a compulsory course. Most of the students attended lectures in education and health-related studies. Therefore, the response rate was quite high. For business and economics studies, the response rate was high among those who were present at the lectures, but the attendance rate was quite low (around 30 per cent). Representativeness of this non-random sample has not been evaluated in this study. Previous research indicates this non-random sample contains students with marginally higher qualifications than the average student (Bonesrønning \& Opstad, 2015). 
Table 2. Factor analysis

\begin{tabular}{l|l|l}
\hline Dimension & Items & Loading \\
\hline \multirow{4}{*}{ Career } & 2 Excellent job opportunities & 0.877 \\
\cline { 2 - 3 } & 3 High probability of getting relevant work & 0.787 \\
\cline { 2 - 3 } 4evelopment skills & 2 Great career opportunities & 0.643 \\
\cline { 2 - 3 } & 21 Strategic thinking and planning & 0.976 \\
\cline { 2 - 3 } & 22 Developing creativity and new ideas & 0.652 \\
\hline Contribution/Commitment & $\begin{array}{l}\text { 24 Preparation for leadership roles } \\
\text { others }\end{array}$ & 0.769 \\
\cline { 2 - 3 } & $\begin{array}{l}\text { 28 The work gives opportunities to contribute } \\
\text { to the society }\end{array}$ & 0.870 \\
\hline
\end{tabular}

Table 3. Descriptive statistics (seven-point Likert scale where $1=$ strongly disagree and $7=$ strongly agree)

\begin{tabular}{|c|c|c|c|c|c|c|c|}
\hline & Min & $\operatorname{Max}$ & Mean & Std. Dev. & Skewness & Kurtosis & Reliability $^{*}$ \\
\hline High salary & 1.00 & 7.00 & 3.4891 & 1.60017 & 0.058 & -0.757 & \\
\hline Enjoyment ( it is a job I enjoy) & 2.00 & 7.00 & 5.5620 & 1.14315 & -0.604 & -0.104 & \\
\hline $\begin{array}{l}\text { Aptitude (it fits with my } \\
\text { abilities) }\end{array}$ & 2.00 & 7.00 & 5.7153 & 1.11110 & -1.080 & 1.181 & \\
\hline I want to work with people & 1.00 & 7.00 & 5.2687 & 1.48761 & -0.709 & -0.004 & \\
\hline $\begin{array}{l}\text { Previous study suggests that I } \\
\text { am skilled in this area }\end{array}$ & 1.00 & 7.00 & 4.7000 & 1.69198 & -0.600 & -0.370 & \\
\hline $\begin{array}{l}\text { It requires skills that I'm good } \\
\text { at }\end{array}$ & 1.00 & 7.00 & 5.4444 & 1.24988 & -1.152 & 1.903 & \\
\hline $\begin{array}{l}\text { The job will bring great } \\
\text { personal satisfaction }\end{array}$ & 1.0 & 7.00 & 4.971 & 1.4294 & -0.638 & 0.237 & \\
\hline $\begin{array}{l}\text { I will have varied tasks that refle } \\
\text { my education }\end{array}$ & 1.00 & 7.00 & 5.1630 & 1.27670 & -0.529 & 0.227 & \\
\hline $\begin{array}{l}\text { Job security (it offers long- } \\
\text { term job security) }\end{array}$ & 1.00 & 7.00 & 5.5333 & 1.29176 & -0.908 & 0.868 & \\
\hline Possibility to earn money & 1.00 & 7.00 & 2.7852 & 1.49818 & 0.712 & -0.164 & \\
\hline Career & 1.33 & 7.00 & 4.6594 & 1.16412 & -0.461 & 0.202 & 0.765 \\
\hline Development & 1.67 & 7.00 & 5.0266 & 1.15052 & -0.289 & -0.287 & 0.731 \\
\hline Contribution & 1.50 & 7.00 & 5.2862 & 1.30536 & -0.431 & -0.422 & 0.857 \\
\hline Extraversion & 2.50 & 6.00 & 3.6612 & 0.56476 & 0.527 & 1.601 & 0.759 \\
\hline Agreeableness & 2.75 & 6.33 & 4.5966 & 0.71440 & -0.270 & -0.218 & 0.590 \\
\hline Conscientiousness & 2.75 & 6.33 & 4.4432 & 0.76010 & -0.128 & -0.600 & 0.613 \\
\hline Emotional stability & 1.00 & 5.50 & 3.5477 & 0.91691 & -0.016 & -0.237 & 0.657 \\
\hline Openness ${ }^{\star *}$ & 2.00 & 7.00 & 4.4312 & 1.08998 & 0.073 & -0.040 & 0.634 \\
\hline Valid N (listwise) & 135 & \multicolumn{6}{|c|}{ ** Due to low reliability, one item was removed. * Cronbach's alpha } \\
\hline
\end{tabular}

\section{Methodology}

The design of the questions was inspired by other articles aiming to capture different dimensions (Davies \& Tikoo, 2019; Easterling \& Smith, 2008; Granitz et al., 2014; Lechner et al., 2018; Malgwi et al., 2005; Siegall et al., 2007). A factor analysis was carried out to identify and reduce the number of dimensions. The results are presented in Table 2, with four different dimensions. 
Many items did not meet the requirements for inclusion. The values for reliability, skewness and kurtosis were within the accepted range (see Table 3).

The 20-item version of the Big Five Inventory (BFI-20) is the version used by Engvik and Clausen (2011), but due to low reliability only three items were included in openness.

Using a t-test, there will be a pairwise comparison of means of the two groups of students. This method does not take into account how different factors affect the results simultaneously.

\section{The Model}

A linear regression model makes it possible to study the different influences by controlling for other factors. The model specification is:

$$
\mathrm{Y} i j=a_{0}+a_{1} \mathrm{X} 1+a_{2} \mathrm{X} 2+a_{3} \mathrm{X} 3+a_{4} \mathrm{X} 4+a_{5} \mathrm{X} 5+a_{6} \mathrm{X} 6+\varepsilon
$$

where

Yij = Endogenous variable

$\mathrm{i}=$ (1) Career, (2) Development, (3) Contribution/commitments, (4) Aptitude, (5) Job security, (6) Enjoyment ( 1 = strongly disagree, 7 = strongly agree)

$\mathrm{j}=(1)$ Business and economics, Group 1 (2) Education and healthcare-related, Group 2

$\alpha_{0}=$ Constant

$\mathrm{X}_{1}=\operatorname{Gender}(1=\mathrm{F}, 0=\mathrm{M})$

$\mathrm{X}_{2}=$ Extraversion (1-7 Likert scale, $1=$ strongly disagree, $7=$ strongly agree)

$\mathrm{X}_{3}=$ Agreeableness (1-7 Likert scale, $1=$ strongly disagree, $7=$ strongly agree)

$\mathrm{X}_{4}=$ Emotional stability (1-7 Likert scale, $1=$ strongly disagree, $7=$ strongly agree)

$\mathrm{X}_{5}=$ Conscientiousness (1-7 Likert scale, $1=$ strongly disagree, $7=$ strongly agree)

$\mathrm{X}_{6}=$ Openness (1-7 Likert scale, $1=$ strongly disagree, 7 = strongly agree)

$\varepsilon=$ Stochastic error

There is no access to experimental data. For this reason, one cannot claim a causal relationship even there is a correlation between the independent variables and the dependent variables.

\section{Results}

Table 3 shows high values for most of the variables, but with some exceptions. The possibility to earn money and high salary have lower scores than the other factors. Among the personality traits, contributions score highly, while extraversion and emotional stability have values below average.

The comparison of means (Table 4) reveals substantial differences in the two student groups. Financial rewards score significantly higher among business and economics students (high salary, possibility to earn money). Career opportunities are also favoured by those students (significance level $<10 \%$ ). For many other dimensions, there are significantly higher values for tasks reflecting education, job security, contribution/commitments, and working with people among students connected to education and healthcare-related fields. This confirms hypothesis 1. 
Students belonging to education and healthcare got score higher on all the personality traits than students connected to business and economics, but the difference is only statistically significant for the trait emotional stability.

Only 10 per cent of students linked to education and healthcare-related courses are males, while the gender distribution is quite similar among business and economics students. This might influence the results. Therefore, Table 3 also presents the mean differences only for female students. However, this does not change the picture of substantial differences among the two groups of students. For some dimensions, the impacts are stronger. For instance, the mean differences for enjoyment, aptitude and job satisfaction are greater and statistically significant. For other variables, the differences are smaller (for instance, career and job security).

Table 4. Comparing the mean values for students with a background in business and economics with those of students with a background in education and healthcare (t-test, 2tailed)

\begin{tabular}{|l|c|c|c|c|c|c|}
\hline & \multicolumn{3}{|c}{ All students } & \multicolumn{3}{c}{ Females only } \\
\hline & Mean Diff & $\mathrm{t}$ & Sig. & Mean Diff & $\mathrm{t}$ & Sig. \\
\hline High salary & 1.84092 & 7.770 & 0.000 & 1.68182 & 5.775 & 0.000 \\
\hline Enjoyment (it is a job I enjoy) & -0.30056 & -1.482 & 0.141 & -0.54554 & -2.430 & 0.017 \\
\hline Aptitude (it fits with my abilities) & -0.25255 & -1.278 & 0.203 & -0.58091 & -2.554 & 0.012 \\
\hline I want to work with people & -1.13953 & -4.557 & 0.000 & -1.22981 & -4.268 & 0.000 \\
\hline $\begin{array}{l}\text { Previous study suggests that I am } \\
\text { skilled in this area }\end{array}$ & 0.118950 & 0.380 & 0.705 & 0.15552 & 0.416 & 0.678 \\
\hline It requires skills that I'm good at & -0.21552 & -0.959 & 0.339 & -0.40020 & -1.589 & 0.116 \\
\hline The job will bring great personal & -0.45850 & -1.815 & 0.072 & -0.7456 & -2.633 & 0.010 \\
\hline satisfaction & & & & & & \\
\hline I will have varied tasks that reflect & -0.59882 & -2.692 & 0.008 & -0.70059 & -2.479 & 0.015 \\
\hline my education & & & & & & \\
\hline Possibility to earn money & 1.02443 & 4.011 & 0.000 & 1.01368 & 3.472 & 0.001 \\
\hline Job security (it offers long-term & -0.76459 & -3.438 & 0.001 & -0.54379 & -2.461 & 0.016 \\
\hline job security) & & & & & & \\
\hline Career & 0.54273 & 2.692 & 0.008 & 0.40467 & 1.733 & 0.087 \\
\hline Development & -0.19879 & -0.975 & 0.331 & -0.27778 & -1.155 & 0.251 \\
\hline Contribution/commitments & -1.18205 & -5.663 & 0.000 & -1.19886 & -5.220 & 0.000 \\
\hline Extraversion & -0.11568 & -1.158 & 0.249 & -0.05429 & -0.453 & 0.652 \\
\hline Agreeableness & -0.15689 & -1.243 & 0.216 & -0.15357 & -1.126 & 0.263 \\
\hline Conscientiousness & -0.20663 & -1.543 & 0.125 & -0.10432 & -0.688 & 0.493 \\
\hline Emotional stability & -0.69621 & -4.591 & 0.000 & -0.95360 & -5.585 & 0.000 \\
\hline Openness & -0.02432 & -0.126 & 0.900 & -0.32607 & -1.421 & 0.159 \\
\hline & & & & & & \\
\hline
\end{tabular}

No personality traits were significantly related to careers for the two groups (Table 5a). There is a positive significant correlation between development and agreeableness and openness for Group 1, but no such impacts were registered for Group 2. However, there is a positive association connected to gender in favour of females for Group 2 (significance $<10 \%$ ). For both student groups, the personality trait agreeableness is positively linked to contribution/commitment (with B around 0.5 for both), but there is a lower level of significance for education and healthcare-related students. Personality traits had different effect on students' aptitude. 
Table 5a. Results from regression model: dependent variables career and development (unstandardised coefficient B)

\begin{tabular}{|c|c|c|c|c|c|c|c|c|c|c|c|c|}
\hline & \multicolumn{6}{|c|}{ Career } & \multicolumn{6}{|c|}{ Development } \\
\hline & \multicolumn{3}{|c|}{$\begin{array}{c}\text { Business and } \\
\text { Economics }\end{array}$} & \multicolumn{3}{|c|}{$\begin{array}{c}\text { Education and } \\
\text { Healthcare }\end{array}$} & \multicolumn{3}{|c|}{$\begin{array}{c}\text { Business and } \\
\text { Economics }\end{array}$} & \multicolumn{3}{|c|}{$\begin{array}{c}\text { Education and } \\
\text { Healthcare }\end{array}$} \\
\hline & $\mathrm{B}$ & $\mathrm{t}$ & Sig. & $\mathrm{B}$ & $t$ & Sig. & $\mathrm{B}$ & $\mathrm{t}$ & Sig. & $\mathrm{B}$ & $t$ & Sig. \\
\hline (Constant) & 2.989 & 2.182 & 0.032 & 2.048 & 1.071 & 0.290 & -0.783 & -0.556 & .580 & 4.794 & 2.696 & .010 \\
\hline Gender & -0.293 & -1.070 & 0.288 & 0.226 & 0.376 & 0.709 & 0.189 & 0.672 & 0.504 & 0.970 & 1.735 & 0.090 \\
\hline Extraversion & 0.331 & 1.473 & 0.145 & -0.079 & -0.265 & 0.792 & 0.265 & 1.148 & 0.255 & -0.237 & -0.850 & 0.400 \\
\hline Agreeableness & 0.205 & 1.241 & 0.218 & 0.353 & 1.014 & 0.316 & 0.462 & 2.724 & 0.008 & -0.387 & -1.194 & 0.239 \\
\hline Conscientiousness & 0.071 & 0.433 & 0.666 & 0.383 & 1.269 & 0.211 & 0.131 & 0.777 & 0.440 & 0.466 & 1.657 & 0.105 \\
\hline Emotional stability & 0.055 & 0.383 & 0.703 & -0.018 & -0.080 & 0.936 & 0.171 & 1.172 & 0.245 & 0.074 & 0.351 & 0.727 \\
\hline \multirow[t]{2}{*}{ Openness } & -0.138 & -1.164 & 0.248 & -0.224 & -1.365 & 0.179 & 0.328 & 2.684 & 0.009 & -0.055 & -0.360 & 0.721 \\
\hline & \multicolumn{3}{|c|}{$\mathrm{N}=85$} & \multicolumn{3}{|c|}{$\mathrm{N}=48$} & \multicolumn{3}{|c|}{$\mathrm{N}=85$} & \multicolumn{2}{|r|}{$\mathrm{N}=48$} & Adj. $R$ square $=0.018$ \\
\hline
\end{tabular}

Table 5b. Results from regression model: dependent variables contribution/commitment and aptitude (unstandardised coefficient B)

\begin{tabular}{|c|c|c|c|c|c|c|c|c|c|c|c|c|}
\hline \multicolumn{7}{|c|}{ Contribution/commitments } & \multicolumn{6}{|c|}{ Aptitude (it fits with my abilities) } \\
\hline & \multicolumn{3}{|c|}{$\begin{array}{c}\text { Business and } \\
\text { Economics }\end{array}$} & \multicolumn{3}{|c|}{$\begin{array}{c}\text { Education and } \\
\text { Healthcare }\end{array}$} & \multicolumn{3}{|c|}{$\begin{array}{c}\text { Business and } \\
\text { Economics }\end{array}$} & \multicolumn{3}{|c|}{$\begin{array}{c}\text { Education and } \\
\text { Healthcare }\end{array}$} \\
\hline & $\mathrm{B}$ & $T$ & Sig. & B & $\mathrm{t}$ & Sig. & B & $\mathrm{t}$ & Sig. & B & $\mathrm{t}$ & Sig. \\
\hline (Constant) & -1.232 & -0.806 & 0.423 & 4.199 & 2.811 & 0.007 & 1.650 & 1.185 & 0.239 & 1.922 & 1.305 & .199 \\
\hline Gender & 0.435 & 1.424 & 0.158 & 0.395 & 0.840 & 0.406 & -0.368 & -1.326 & 0.189 & 0.573 & 1.243 & 0.221 \\
\hline Extraversion & 0.089 & 0.356 & 0.723 & 0.220 & 0.939 & 0.353 & -0.064 & -0.281 & 0.780 & 0.201 & 0.878 & 0.385 \\
\hline Agreeableness & 0.534 & 2.897 & 0.005 & 0.503 & 1.849 & 0.072 & 0.363 & 2.165 & 0.033 & 0.406 & 1.528 & 0.134 \\
\hline Conscientiousness & 0.146 & 0.795 & 0.429 & -0.248 & -1.051 & 0.299 & 0.286 & 1.710 & 0.091 & -0.237 & -1.006 & 0.320 \\
\hline Emotional stability & 0.329 & 2.073 & 0.041 & -0.065 & -0.364 & 0.718 & -0.042 & -0.290 & 0.772 & 0.386 & 2.208 & 0.033 \\
\hline \multirow[t]{2}{*}{ Openness } & 0.313 & 2.359 & 0.021 & -0.063 & -0.490 & 0.627 & 0.371 & 3.072 & 0.003 & 0.076 & 0.605 & 0.548 \\
\hline & \multicolumn{3}{|c|}{$\mathrm{N}=85$} & \multicolumn{3}{|c|}{$\mathrm{N}=48$} & \multicolumn{3}{|c|}{$\mathrm{N}=85$} & Adj. F & $\mathrm{N}=48$ & \\
\hline
\end{tabular}

Table 5c. Results from regression model: dependent variables enjoyment and job security (unstandardised coefficient B)

\begin{tabular}{|c|c|c|c|c|c|c|c|c|c|c|c|c|}
\hline \multicolumn{7}{|c|}{ Enjoyment } & \multicolumn{6}{|c|}{ Job security } \\
\hline & \multicolumn{3}{|c|}{$\begin{array}{c}\text { Business and } \\
\text { Economics }\end{array}$} & \multicolumn{3}{|c|}{$\begin{array}{c}\text { Education and } \\
\text { Healthcare }\end{array}$} & \multicolumn{3}{|c|}{$\begin{array}{c}\text { Business and } \\
\text { Economics }\end{array}$} & \multicolumn{3}{|c|}{$\begin{array}{c}\text { Education and } \\
\text { Healthcare }\end{array}$} \\
\hline & $B$ & $\mathrm{t}$ & Sig & $B$ & $\mathrm{t}$ & Sig & $B$ & $\mathrm{t}$ & Sig & $B$ & $t$ & Sig \\
\hline (Constant) & 1.983 & 1.511 & 0.193 & 1.273 & 0.840 & 0.406 & $0-.405$ & -0.283 & 0.778 & 4.164 & 2.637 & 0.012 \\
\hline Gender & -0.264 & 0.302 & 0.385 & 0.376 & 0.792 & 0.433 & 0.629 & 2.180 & 0.032 & 0.194 & 0.393 & 0.696 \\
\hline Extraversion & 0.216 & 0.248 & 0.387 & 0.294 & 1.245 & 0.220 & 0.272 & 1.140 & 0.258 & 0.138 & 0.561 & 0.578 \\
\hline Agreeableness & 0.385 & 0.182 & 0.038 & 0.545 & 1.992 & 0.053 & 0.684 & 3.976 & 0.000 & 0.476 & 1.671 & 0.102 \\
\hline Conscientiousness & 0.014 & 0.181 & 0.938 & -0.090 & -0.371 & 0.713 & 0.139 & 0.806 & 0.423 & 0.252 & 1.000 & 0.323 \\
\hline Emotional stability & 0.111 & 0.157 & 0.481 & 0.236 & 1.312 & 0.197 & 0.302 & 2.030 & 0.046 & -0.205 & -1.094 & 0.280 \\
\hline \multirow[t]{2}{*}{ Openness } & 0.146 & 0.131 & 0.268 & -0.013 & -0.102 & 0.919 & -0.087 & -0.705 & 0.483 & -0.314 & -2.339 & 0.024 \\
\hline & \multicolumn{3}{|c|}{$\mathrm{N}=85$} & \multicolumn{3}{|c|}{$\mathrm{N}=48$} & \multicolumn{3}{|c|}{$\mathrm{N}=85$} & \multicolumn{3}{|c|}{$\mathrm{N}=48$} \\
\hline
\end{tabular}


For business and economics students, the correlation is positive and statistically strong between aptitude and agreeableness and openness, and also positive for the dimension conscientiousness (significance $<10 \%$ ). For Group 2, only the trait emotional stability is positively linked to aptitude. The dimension enjoyment is positively related to both student categories, but with a higher B-value for those connected to the education and healthcare sectors. In terms of the job security issue, there are substantial differences among the students in this survey. For business and economics students, there is a pronounced positive relationship between agreeableness and gender

Females prefer job security to a higher degree than their male peers. Furthermore, there is a positive relationship between emotional stability and job security for undergraduates within business and economics. For the other students, only openness is associated with job security, and with a negative connection $(B=-0.314)$. The findings from the regression model confirm hypothesis $2(\mathrm{H} 2)$. At the same time, there is confirmation that links to personal characteristics are different for the two student groups and a trade-off between financial rewards and other job benefits $(\mathrm{H} 1)$.

\section{Discussion}

In view of theory and previous research, many of the results in this analysis are consistent with what one might expect based on the selected student groups. There are two groups that have chosen completely different directions and are in different stages in their working life, but they have an important common feature, namely they want to learn more about economics and business administration. Group 1 has a small predominance of women; it consists of students in their twenties and with little professional experience. They can choose different career paths (public or private sector, within different service areas, small or large enterprises). Students belonging to Group 2 have deliberately selected a person-oriented sector and have several years' professional experience. In Norway, this means in practice being a public employee, since education and health services are part of the public sector. Approximately 90 per cent of the students in this group are women.

There is considerable optimism among the students in both groups. The average student looks positively at job opportunities that are adapted to their wishes and preferences (see Table 2).

\section{Trade-off between High Salaries and Other Job Benefits}

The findings in this paper are in line with the reports by Lechner et al. (2018) and Redmond and McGuinness (2019). Students who have decided to work in the public sector (teachers, nurses and more) pay less attention than economics and business students to financial rewards but report significantly higher values in factors such as job security, working with people, contribution/commitments, varied assignments and personal satisfaction (see Table 3). This is an indicator of trade-off between pay and other preferences associated with the job. The reason that most students in the health and education sector are women might be that they have different work values, in line with the findings of Lechner et al. (2018). However, this paper has indicated substantial differences between females studying business and economics and those studying pedagogical and healthcare subjects (see Table 3). One would expect smaller mean differences by only comparing females from the two groups, while the opposite was true for several factors, including personal satisfaction, enjoyment and aptitude. For the last two last factors, the differences are statistically significant. One interpretation of this is that the 
differences between the two student groups in this analysis are due to factors other than gender. Obviously, female business and economics students have different preferences to females within education and healthcare. The regression models confirmed this picture, since gender did not have a significant impact on the dependent variables, except for job security among business and economics students.

This paper did not find any significant mean differences related to career and development, supporting the conclusions of Quinn et al. (2019). A reason for this result might be the selection of students from education and healthcare. These are students who have career ambitions, and perhaps to the same degree as economics and business students.

\section{The Link between Personality Traits and Career and Job Opportunities}

Since personality traits are central to the analysis of hypothesis 2 , it may be of interest to see if there are different values according to the two student groups. In line with the literature review, students from education and the health sector tend to have higher values only for emotional stability. This difference in this study is statistically significant (see Table 3).

The regression model gave different results for the two student groups, but there are also some similar findings (Table 5). There is a positive link between agreeableness and contribution/commitments. The coefficient B had about the same value, but there was slightly weaker significance for education and health sector students. People with a high score on agreeableness like to collaborate and help others. Hence, it is reasonable to assume that there is a positive relationship between agreeableness and contribution/commitments (Lee et al., 2020). Both groups also show positive correlation between agreeableness and enjoyment. This is in line with the findings of Lodewyk and Gao (2020). Agreeableness is associated with enjoyment. There is no significant connection between the personality traits and career for either Group 1 or Group 2.

\section{Business and Economics Students}

The link between personality traits and business and economics students is quite consistent with prior research. People who are open to new ideas are creative and promote development. Hence, there was a logical positive correlation between openness and development. For agreeableness, previous results are more mixed, but in line with Eshet and Harpaz (2021), there was a significant positive relationship between development and agreeableness. Honest and trust can cultivate a good atmosphere that helps to create new ideas.

Guo et al. (2021) argued that people with high scores on openness can think 'outside the box' and can be very supportive. Therefore, one can expect a positive relationship between openness and contribution as reported in this study, and between aptitude and openness. This study confirmed these relationships.

There was a significant positive correlation between job security and the two independent variables agreeableness and gender in favour of females. This result is consistent with the findings of Wu et al. (2020), and that females tend to prefer secure jobs to a higher degree than males (Lechner et al., 2018; Redmond \& McGuinness, 2019). Since women are more risk averse than males (Buser et al., 2017), it might explain why they prioritise secure jobs more than males. The regression models showed a significant gender impact only for this independent variable. Although the literature pointed out there might be a significant gender gap 
among business and economics students (Ahlstrom \& Asarta, 2019), this was only partly confirmed in this paper (in regard to job security).

\section{Education and Healthcare-related Students}

Looking at Group 2, the regression models indicates that personality traits only have minor impacts (in contrast to Group 1). An example of an effect that applies only to this group in this study is the positive correlation between aptitude and emotional stability.

However, the analysis showed no connection between job security and agreeableness for Group 2. Only the personality trait openness had significant influence (negatively). One explanation may be that for students in Group 2, job security is very high. They have chosen a profession where there is a shortage of professionals. This may, of course, affect the answers. They know the job security is high. This may be consistent with the findings of Flinn et al. (2020), who argued there may be significant differences in how the labour market values different specific personal characteristics. Therefore, personality traits can make different impacts depending on which parts of the work team one is studying. Following this reasoning, different outcomes can be expected when comparing the public and private sectors. Another explanation factor is that the participants in this analysis belonged to a fairly homogeneous group.

\section{Contribution}

The findings are useful for gaining insight into why students select different pathways in the labour market. Their choice is connected to personal characteristics, preferences and desires. There are also gender differences. Females and males have different preferences. It is important for the university administration to inform students about different job opportunities and adapt the study programmes to the different student groups.

\section{Limitations}

Business and economics students belonged to only one university. These are students without professional experience. The questions were about their expectations in the labour market. There might be some bias in comparison to the other group where the participants have several years' professional experience. Furthermore, the sample in Group 2 is significantly smaller than the Group 1 sample. This has implications for the detection of any significant statistical effects.

The public sector is big in Norway and offers good working conditions. This can set some limits on the validity of the results, but they are still relevant from an international perspective.

\section{Conclusion}

There is good prosperity in Norway, with low unemployment rates. One out of three people works in the public sector in Norway, and this is considerable in an international comparison. Students' positive attitudes towards career opportunities and personal appreciations must be seen in this context. 
Business students often aspire to managerial careers. Hence, they are comparable to people who have professional jobs within education and healthcare and who have decided to take further education in administration and management.

This study confirmed significant differences between the two student groups. The findings suggested a trade-off effect between financial rewards and other job qualities. Education and healthcare students working in the public sector put less emphasis on the level of wages in exchange for other job benefits such as security, enjoyment and personal satisfaction. For economics and business students, the reverse is true: wages mean more, and they are willing to forsake other advantages related to their job. This seemed to be a distinction between those who prefer employment in the public or private sector.

There is also a gender gap. Women are more attracted to jobs that provide qualities other than high wages. The analysis suggested there was a minor gender variance for business and economics students. However, there was a significant difference between Groupc1 and Group 2 independent of gender. It means, females choosing business and economics studies have different preferences than females choosing management in person-related occupations like teachers and nurses.

There is a correlation between different career pathways and personal characteristics. High agreeableness is positively correlated with job security, contributions to society and helping others. All in all, there is a stronger link between personality traits and labour conditions for Group 1 (business and economics students) than for Group 2 (students related to the health and education sector).

\section{References}

Ahlstrom, L. J., \& Asarta, C. J. (2019). The gender gap in undergraduate economics course persistence and degree selection. AEA Papers and Proceedings, 109, 255-260.

Asif, A., Ansari, N., \& Rathore, K. (2015). Empirical relationship of Big Five personality traits and affective commitment among the public sector employees. International Journal of Management Sciences and Business Research, 6(1S), 177-182. doi.org/10.1111/j.1744-6570.1991.tb00688.x

Baker, R., Bettinger, E., Jacob, B., \& Marinescu, I. (2018). The effect of labor market information on community college students' major choice. Economics of Education Review, 65, 18-30. doi.org/10.1016/j.econedurev.2018.05.005

Bonesrønning, H., \& Opstad, L. (2015). Can student effort be manipulated? Does it matter? Applied Economics, 47(15), 1511-1524. doi.org/10.1080/00036846.2014.997923

Buser, T., Peter, N., \& Wolter, S. C. (2017). Gender, competitiveness, and study choices in high school: Evidence from Switzerland. American Economic Review, 107(5), 125-130. doi.org/10.1257/aer.p20171017

Çelik, G. T., \& Oral, E. L. (2016). Big Five and organizational commitment: The case of Turkish construction professionals. Human Resource Management Research, 6(1), 6-14. 
Clariana, M. (2013). Personality, procrastination and cheating in students from different university degree programs. Electronic Journal of Research in Educational Psychology, 11(2), 451-472. http://dx.doi.org/10.14204/ejrep.30.13030

Cogliser, C. C., Gardner, W. L., Gavin, M. B., \& Broberg, J. C. (2012). Big five personality factors and leader emergence in virtual teams: Relationships with team trustworthiness, member performance contributions, and team performance. Group \& Organization Management, 37(6), 752-784. doi.org/10.1177/1059601112464266

Costa, P. T., \& McCrae, R. R. (1995). Domains and facets: Hierarchical personality assessment using the revised Neo Personality Inventory. Journal of Personality Assessment, 64, 21-50, 234.

Cox, K. S., Wilt, J., Olson, B., \& McAdams, D. P. (2010). Generativity, the Big Five, and psychosocial adaptation in midlife adults. Journal of Personality, 78(4), 1185-1208. doi.org/10.1111/j.14676494.2010.00647.x

Davies, M. A., \& Tikoo, S. (2019). Motives driving the choice of a business concentration: A four-country study of marketing, accounting and finance, and management undergraduates. Journal of Marketing Education, 41(3), 185-201. doi.org/10.1177/0273475318773501

Easterling, D. S., \& Smith, K. (2008). A factor-analytic investigation of students' perceptions regarding purpose, choice of major, and future work. Journal of College and Character, 10(2). doi.org/10.2202/1940-1639.1072

Engvik, H., \& Clausen, S. (2011). Norsk kortversjon av big five inventory (BFI-20). Tidsskrift for norsk psykologforening, 48(9), 869-872. (In Norwegian).

Eshet, Y., \& Harpaz, I. (2021). Outstanding employees' performance: Personality traits, innovation and knowledge management. In Proceedings of the 54th Hawaii International Conference on System Sciences (p. 5024).

Flinn, C., Todd, P., \& Zhang, W. (2020). Personality traits, job search and the gender wage gap. Cambridge Working Papers in Economics, 2053.

Gokoglan, E., \& Ozen Bekar, E. (2021). The relationship of nurse managers' personality traits on their conflict management strategy preferences. Journal of Nursing Management. doi.org/10.1111/jonm. 13262

Granitz, N., Chen, S., \& Kohli, K. K. (2014). Choosing business as a college major: A survey of high school students. Journal of the Academy of Business Education, 15(1),11-32.

Guo, J., Zhang, J., \& Pang, W. (2021). Parental warmth, rejection, and creativity: The mediating roles of openness and dark personality traits. Personality and Individual Differences, 168, 110369. doi.org/10.1016/j.paid.2020.110369

Hager, F. (2021). The Impact of Personality Traits on the Burnout promoting Effect of poor Supervisor Support. International Journal of Social Sciences, 10(1), 17-38. doi.org/10.20472/SS2021.10.1.002

Houston, D. J. (2000). Public-service motivation: A multivariate test. Journal of Public Administration Research and Theory, 10(4), 713-728. doi.org/10.1093/oxfordjournals.jpart.a024288 
Howard, A., \& Bray, D. W. (1990). Predictions of managerial success over long periods of time: Lessons from the Management Progress Study. In K. E. Clark \& M. B. Clark (Eds.), Measures of leadership (p. 113-130). Leadership Library of America.

Hübler, D., \& Hübler, O. (2006). Is there a trade-off between job security and wages in Germany and the UK? IZA Discussion Papers, No. 2241. Institute for the Study of Labor (IZA), Bonn.

Jackson, D., \& Wilton, N. (2016). Career management attitudes among business undergraduates. Australian Journal of Career Development, 25(1), 7-22. doi.org/10.1177/1038416215604002

Judge, T. A., Higgins, C. A., Thoresen, C. J., \& Barrick, M. R. (1999). The big five personality traits, general mental ability, and career success across the life span. Personnel Psychology, 52(3), 621652. doi.org/10.1111/j.1744-6570.1999.tb00174.x

Lakhal, S., Frenette, É., Sévigny, S., \& Khechine, H. (2012). Relationship between choice of a business major type (thing-oriented versus person-oriented) and Big Five personality traits. The International Journal of Management Education, 10(2), 88-100. doi.org/10.1016/j.ijme.2012.03.003

Lechner, C. M., Sortheix, F. M., Obschonka, M., \& Salmela-Aro, K. (2018). What drives future business leaders? How work values and gender shape young adults' entrepreneurial and leadership aspirations. Journal of Vocational Behavior, 107, 57-70. doi.org/10.1016/j.jvb.2018.03.004

Lee, H. W., Kim, S., \& Liew, J. (2020). Spectator sports as context for examining observers' agreeableness, social identification, and empathy in a high-stakes conflict situation. Psychological Reports, 0033294120948228. doi.org/10.1177/0033294120948228

Leóna, F. R. (2017). Is experience in the public sector associated with Big Five personality aspects? LIBERABIT. Revista Peruana de Psicología, 23(1), 103-109. doi.org/10.24265/liberabit.2017.v23n1.07

Levitats, Z., \& Vigoda-Gadot, E. (2020). Emotionally engaged civil servants: Toward a multilevel theory and multisource analysis in public administration. Review of Public Personnel Administration, 40(3), 426-446. doi/org/ 10.1177/0734371X18820938

Lievens, F., Coetsier, P., De Fruit, F., \& De Maeseneer, J. (2002). Medical students' personality characteristics and academic performance: A five-factor model perspective. Medical Education, 36, 1050-1056.

Lisnerova, R., \& Urbanová, E. (2020). Managerial Competencies and Education Need of School Headmasters in the Czech Republic. International Journal of Teaching and Education, 8(1), 33-46.doi.org/10.20472/TE.2020.8.1.003

Lodewyk, K. R., \& Gao, Z. (2020). Path associations between trait personality, enjoyment, and effort by gender in high school physical education. International Journal of Sport and Exercise Psychology, 18(1), 108-119. doi.org/10.1080/1612197X.2018.1478871

Malgwi, C. A., Howe, M. A., \& Burnaby, P. A. (2005). Influences on students' choice of college major. Journal of Education for Business, 80(5), 275-282. doi.org/10.3200/JOEB.80.5.275-282

Prysmakova, P. (2020). Contact with citizens and job satisfaction: Expanding person-environment models of public service motivation. Public Management Review, 1-20. doi.org/10.1080/14719037.2020.1751252 
Quinn, J. F., Cahill, K. E., \& Giandrea, M. D. (2019). Transitions from career employment among publicand private-sector workers. Journal of Pension Economics \& Finance, 18(4), 529-548. doi.org/10.1017/S1474747218000434

Redmond, P., \& McGuinness, S. (2019). The gender wage gap in Europe: Job preferences, gender convergence and distributional effects. Oxford Bulletin of Economics and Statistics, 81(3), 564587. doi.org/10.1111/obes. 1228

Roccas, S., Sagiv, L., Schwartz, S. H., \& Knafo, A. (2002). The big five personality factors and personal values. Personality and Social Psychology Bulletin, 28(6), 789-801. doi.org/10.1177/0146167202289008

Seibert, S. E., \& Kraimer, M. L. (2001). The five-factor model of personality and career success. Journal of Vocational Behavior, 58(1), 1-21. doi.org/10.1006/jvbe.2000.1757

Siegall, M., Chapman, K. J., \& Boykin, R. (2007). Assessment of core courses and factors that influence the choice of major: A 'major' bias. Georgia University of West Georgia. doi.org/10.1007/s10869010-9184-3

Soutar, G. N., \& Turner, J. P. (2002). Students' preferences for university: A conjoint analysis. International Journal of Educational Management. doi.org/10.1108/09513540210415523

Su, R., Rounds, J., \& Armstrong, P. I. (2009). Men and things, women and people: A meta-analysis of sex differences in interests. Psychological Bulletin, 135(6), 859. doi/org/10.1037/a0017364

Sui, L., Qin, H., Ned, J., \& Sun, L. (2021). Personality traits and job exploration among Latino business students: An exploratory investigation. Psychology in the Schools, 58(1), 18-32. https://doi.org/10.1002/pits.22434

Tschirhart, M., Reed, K. K., Freeman, S. J., \& Anker, A. L. (2008). Is the grass greener? Sector shifting and choice of sector by MPA and MBA graduates. Nonprofit and Voluntary Sector Quarterly, 37(4), 668-688. doi:10.1177/0899764008314808

Vedel, A. (2016). Big Five personality group differences across academic majors: A systematic review. Personality and Individual Differences, 92, 1-10. doi.org/10.1016/j.paid.2015.12.011

Wiswall, M., \& Zafar, B. (2015). How do college students respond to public information about earnings? Journal of Human Capital, 9(2), 117-169.

Wu, C. H., Wang, Y., Parker, S. K., \& Griffin, M. A. (2020). Effects of chronic job insecurity on Big Five personality change. Journal of Applied Psychology, 105(11), 1308-1326. doi.org/10.1037/apl0000488

Yu, W. H., \& Kuo, J. C. L. (2017). The motherhood wage penalty by work conditions: How do occupational characteristics hinder or empower mothers? American Sociological Review, 82(4), 744-769. doi.org/10.1177/0003122417712729

Zaidi, N. R., Wajid, R. A., Zaidi, F. B., Zaidi, G. B., \& Zaidi, M. T. (2013). The big five personality traits and their relationship with work engagement among public sector university teachers of Lahore. African Journal of Business Management, 7(15), 1344-1353. 